\title{
Potential of five non-spore-forming bacteria, originated from the European cockchafer, Melolontha melolontha (Linnaeus, 1758) (Coleoptera: Scarabaeidae), on three economic insect pests
}

Ömer Ertürk ${ }^{1 *}$ and Mustafa Yaman²

\begin{abstract}
Five non-spore-forming bacteria were isolated from the European cockchafer, Melolontha melolontha (Linnaeus, 1758) (Coleoptera: Scarabaeidae). Their potential was tested against the three economic insect pests, the great spruce bark beetle, Dendroctonus micans Kugelann (Coleoptera: Curculionidae); the pine processionary, Thaumetopoea pityocampa (Lepidoptera: Thaumetopoeidae); and the gypsy moth, Lymantria dispar (Linn.) (Lepidoptera: Erebidae), to find an effective biological control agent. All isolated bacteria were cultured and identified using VITEK bacterial identification systems and $16 \mathrm{~S}$ rRNA gene sequence analysis. The bacteria were identified as Enterobacter cloacae complex (isolate 1M), Serratia marcescens (isolate 3M), Pseudomonas aeruginosa (isolate 4M), Kocuria kristinae (isolate 5M), and Serratia liquefaciens (isolate 8M). Laboratory experiments, carried out to evaluate the virulence of these isolates, showed that all isolated bacteria had a pathogenic effect on the tested pests. E. cloacae had 35, 56.7, and 84\%; S. marcescens 50, 60.9, and 47.8\%; P. aeruginosa 55, 69.6, and 48\%; K. kristinae 40, 43.5, and 16\%; and S. liquefaciens 45, 65.2, and $36 \%$ mortality rates on the larvae of D. micans, T. pityocampa, and L. dispar, respectively. The isolated bacteria can be considered in integrated pest control programs.
\end{abstract}

Keywords: Melolontha melolontha, Dendroctonus micans, Thaumetopoea pityocampa, Lymantria dispar, Nonspore-forming bacteria, Virulence

\section{Background}

New pest management strategies tend to minimize the impact on the environment and non-target organisms (Ruiu et al. 2013). Entomopathogens have relative specificity and lower environmental impact. The successful use of entomopathogens results in an alternative pest management for insect control. Among them, bacteria and their toxins are the most commercially microbial insecticides used successfully in biological control. Entomopathogenic bacteria such as Bacillus thuringiensis are generally known as lower risk pesticides than chemicals. Current goals

\footnotetext{
*Correspondence: oseerturk@hotmail.com

'Department of Molecular Biology and Genetics, Faculty of Arts and

Sciences, Ordu University, 52750 Ordu, Turkey

Full list of author information is available at the end of the article
}

include searching for entomopathogenic bacteria and determining their potentials (Egami et al. 2009). Entomopathogenic bacteria are commonly isolated from host insects or soil (Thiery and Frachon 1997). Soil plays an important role as a habitat for spore-forming and nonspore-forming entomopathogenic bacteria. While the entomopathogenic bacteria domain has been well represented by spore-forming bacteria, members of Bacillaceae family, non-spore-forming entomopathogenic bacteria have been also documented with insects (Ruiu et al. 2013).

Numerous larvae of Scarabaeidae (Coleoptera) feed on plant materials in the soil, and many of them are known as important plant pests. Scarabs are infected by a number of entomopathogens (Yaman et al. 2016). The European cockchafer, Melolontha melolontha (Linnaeus, 1758) 
(Coleoptera: Scarabaeidae) causes significant economic damage. It is a soil-inhabiting insect pest at the larval stage and possible target for entomopathogenic bacteria in soil.

In this study, isolation and characterization of nonspore-forming bacteria from M. melolontha larvae were presented and their potentials on three economic insect pests were documented.

\section{Material and methods}

\section{Insect samples}

Samples of M. melolontha larvae were collected from Ordu province, Turkey, targeting isolate entomopathogenic bacteria. For bioassay tests, three economic insect pests, namely Dendroctonus micans (Yaman et al. 2010), Thaumetopoea pityocampa, and Lymantria dispar, were used. D. micans larvae were obtained from the forest fields near Ordu, Turkey; their cultures were maintained in a laboratory set up by the Turkish Ministry of Forestry in Ordu province. Lymantria dispar larvae were collected from İzmir province, Turkey, brought to the laboratory, and fed on apple leaves. T. pityocampa larvae were collected from pine trees in Sinop province, Turkey, brought to the laboratory, and fed on fresh pine needles.

\section{Bacterial isolation}

M. melolontha larvae suspected of bacterial symptoms after a macroscopic examination were used for bacterial isolation (Thiery and Frachon 1997). Before the isolation process, the dead larvae were individually placed into $70 \%$ ethanol and gently shaken for 3 min (Yaman et al. 2010). After surface sterilization, considering aseptic conditions samples were washed by a sterilized water. Sterile $1 \mathrm{ml} \mathrm{sy-}$ ringes were used to insert into the hemocoel of the insect. Then, $100 \mu \mathrm{l}$ hemolymph suspension, taken from the hemocoel, was spread on nutrient agar plates. The plates were incubated at $25-36{ }^{\circ} \mathrm{C}$ for $24-48 \mathrm{~h}$. After incubation, the plates were examined and bacterial colonies that were similar in terms of colony and color morphology were selected. Different colony types of bacteria were selected and purified on nutrient agar plates by subculturing. Individual colonies were subcultured twice to ensure purity (Kuzina et al. 2001). One of the subcultured colonies was used for identification of species per isolate.

Bacterial strains were preserved for a long-term storage in nutrient broth with $15 \%$ glycerol at $-86{ }^{\circ} \mathrm{C}$ for further tests at the Department of Molecular Biology and Genetics, Faculty of Arts and Science, Ordu University. The stock culture strains were subcultured onto tryptic soy agar plates to check their purity. All bacterial isolates were initially stained by Gram's dye for the identification of gram-positive or gram-negative bacteria and tested for some biochemical reactions. A standard bacterial suspension was prepared in $1.8 \mathrm{ml}$ of $0.45 \%$ saline, using the VITEK colorimeter for each isolate. The time interval between suspension preparation and card filling was less than $30 \mathrm{~min}$ to avoid changes in turbidity. Then, VITEK bacterial identification systems (bioMerieux, Prod. No 21341 and 21342) were used for the identification of the isolated bacteria. Additionally, all isolated bacteria were further identified, using $16 \mathrm{~S}$ rDNA analysis. For this, pure bacterial suspensions were used for DNA extraction. Equal volumes of bacterial suspension and glass beads were put into an Eppendorf tube and vigorously shaken on the vortex for 1 min at maximum speed. And then, the solutions were incubated by proteinase $\mathrm{K}$ at $56{ }^{\circ} \mathrm{C}$ for $3 \mathrm{~h}$. After that, nucleic acid extraction was performed by the DNA isolation kit, as according to the manufacturer's guidelines and Hyliš et al. (2005) with some modifications. To amplify and sequence the bacterial $16 \mathrm{~S}$ rRNA genes and identify the bacterial isolates, the isolated bacterial DNAs were sent to Sentegen Biotech Company (Ankara, Turkey).

\section{Bioassay tests for potentials of the isolated bacteria}

Virulence of the isolated bacteria was tested against the larvae of $D$. micans, larvae of $T$. pityocampa, and L. dispar. Bacterial isolates were incubated in nutrient broth medium at $30{ }^{\circ} \mathrm{C}$ for $18 \mathrm{~h}$. Bacterial suspensions containing approximately $10^{9}$ bacteria/ml were used in bioassay according to Ben-Dov et al. (1995). D. micans larvae were fed on spruce barks dipped into the bacterial suspensions (Yaman et al. 2010), T. pityocampa larvae on pine needles, and $L$. dispar on apple leaves. Each bioassay group was performed by 30 insect larvae at the same laboratory conditions. All tested groups were kept at $24-28{ }^{\circ} \mathrm{C}$ and $35-45 \% \mathrm{RH}$ and 18:6 photoperiod in laboratory conditions. Observations were recorded daily and dead larvae were removed immediately. All bioassays were repeated three times on different days and data was corrected, using Abbott's formula (Abbott 1925).

\section{Results and discussion}

\section{Isolated bacteria}

In the present study, five non-spore-forming bacteria were isolated from the larvae of $M$. melolontha. These bacteria were identified as Enterobacter cloacae complex (isolate 1M), Serratia marcescens (isolate 3M), Pseudomonas aeruginosa (isolate 4M), Kocuria kristinae (isolate $5 \mathrm{M}$ ), and Serratia liquefaciens (isolate $8 \mathrm{M}$ ) according to the results from VITEK bacterial identification systems and $16 \mathrm{~S}$ rRNA gene sequence analysis.

Isolate $1 \mathrm{M}$ of $M$. melolontha larvae was identified as E. cloacae. It is a rod-shaped, gram-negative, facultatively anaerobic bacterium. Species of the E. cloacae 




complex are widely encountered in nature, and they can act as pathogens (Mezzatesta et al. 2012). Sezen et al. (2007) also found Enterobacter sp. from $M$. melolontha. E. cloacae was observed to be the most common species of the poplar pest, Cryptorhynchus lapathi (Yaman et al. 2017).

Isolate 3M, isolated from $M$. melolontha larvae, was identified as Serratia marcescens (family Enterobacteriaceae). It is a species of rod-shaped, gram-negative and facultative anaerobic bacteria. S. marcescens is one of the best-known and mostly isolated pathogenic bacterium from insects (Thiery and Frachon 1997; Lauzon et al. 2003; PinedaCastellanos et al. 2015). Among the non-spore-forming bacterial genera, the genus Serratia includes more effective entomopathogenic species (O'Callaghan et al. 1996) and would possibly be the bio-control agents against some insects (Sezen et al. 2001).

Isolate 4M isolated from M. melolontha larvae was identified as Pseudomonas aeruginosa. It is a bacil, gram-negative bacterium found throughout the environment. It is known as a potential pathogen for various insects and has frequently been isolated from infected insects, e.g., Schistocerca gregaria (Forski) (Orthoptera: Acrididae), Melanopus spp.
(Orthoptera: Acrididae) (Bucher and Stephens 1959), Galleria mellonella (Linnaeus) (Lepidoptera: Pyralidae) (Lysenko 1963), Stonioxys calcitrans (Linnaeus) (Diptera: Muscidae), Amphimallon solstitialis (Linnaeus) (Coleoptera: Scarabaeidae), and Eurygaster intergriceps (Puton) (Hemiptera: Scutelleridae) (Lipa 1975). This bacterium was isolated from dead larvae of Pieris brassicae (Yaman and Demirbağ 2000). P. aeruginosa had the greatest insecticidal effect $(67 \%)$ on $P$. brassicae (Bucher and Stephens 1959; Yaman and Demirbağ 2000). Bucher and Stephens (1959) found P. aeruginosa as the main cause of disease in grasshoppers, under both laboratory and natural conditions. Obtained results agree with the abovementioned references.

Isolate 5M Kocuria kristinae was another bacterium isolated from M. melolontha in this study. It is a grampositive microorganism. Cockburn et al. (2013) isolated and identified this bacterium from the common bed bug, Cimex lectularius. Yaman and Ertürk (2016) isolated and identified it from Crepidodera aurata (Coleoptera, Chrysomelidae) for the first time, recently.

Isolate 8M Serratia liquefaciens was isolated from $M$. melolontha larvae. It is a species of gram-negative bacteria and the most prevalent Serratia species in the natural

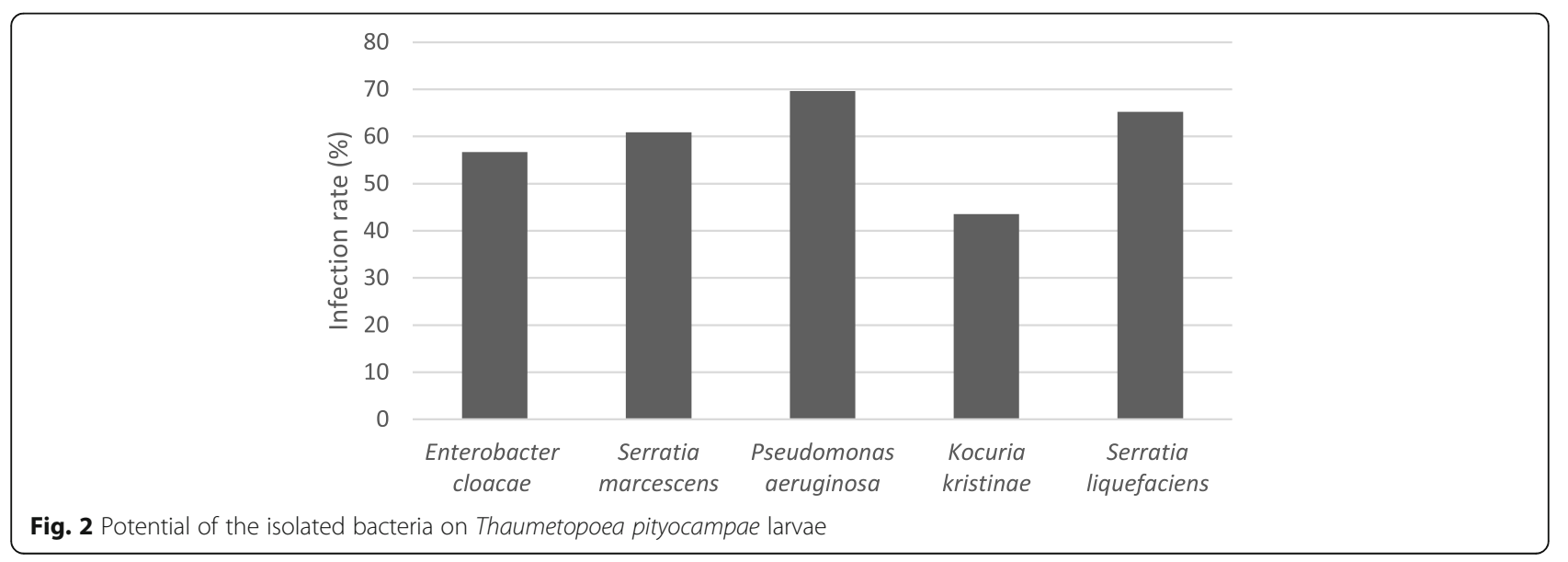




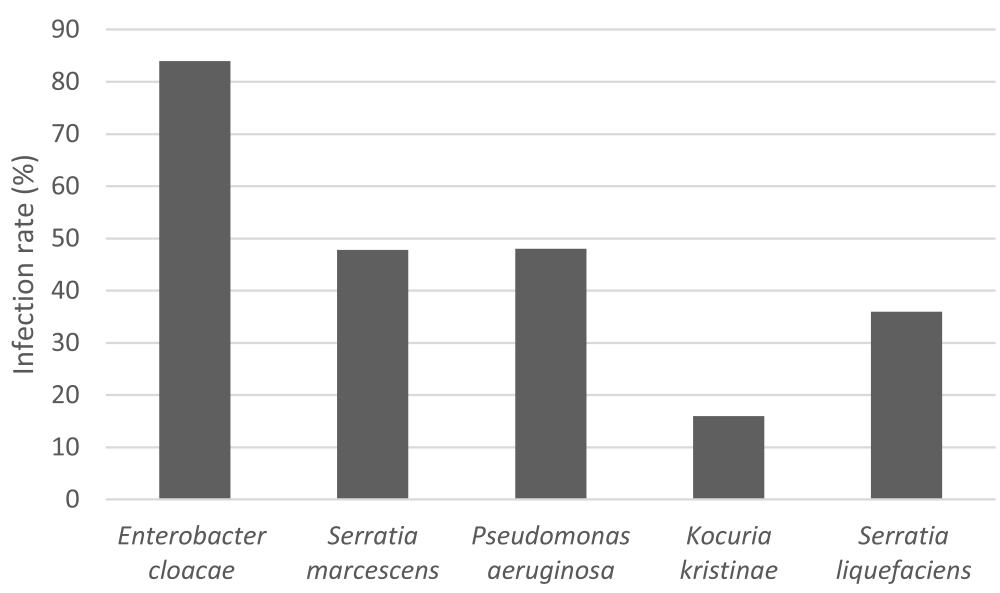

Fig. 3 Potential of the isolated bacteria on Lymantria dispar larvae

environment. This bacterium was diagnosed in Cydia pomonella (Zimmermann et al. 2013). Muratoğlu et al. (2011) isolated this bacterium from Ips typographus. Katı et al. (2017) found both S. marcescens and S. liquefaciens in Xyleborinus saxesenii. Yaman et al. (2017) isolated S. liquefaciens from Cryptorhynchus lapathi.

\section{Bioassay}

Bioassay tests showed that all the isolated bacteria had a pathogenic effect against the three economic insect pests tested with different ratios. E. cloacae had 35\% mortality on $D$. micans larvae, $50 \%$ on $S$. marcescens, $55 \%$ on $P$. aeruginosa, $40 \%$ on K. kristinae, and $45 \%$ on S. liquefaciens (Fig. 1).

Among the tested bacteria, $P$. aeruginosa was the most effective isolate causing $69.6 \%$ mortality rate in the larvae of $T$. pityocampa. The other isolates, E. cloacae, $S$. marcescens, K. kristinae, and S. liquefaciens showed different levels of potential such as 56.7, 60.9, 43.5, and $65.2 \%$ mortality rate on $T$. pityocampa larvae, respectively (Fig. 2).

On the other hand, the bacterial isolates against the 2nd instar larvae of $L$. dispar was tested. E. cloacae was the most effective isolate causing $84 \%$ mortality on the larvae of $L$. dispar. The other isolates, $S$. marcescens, $P$. aeruginosa, K. kristinae, and S. liquefaciens showed different levels of effects such as $47.8,48,16$, and $36 \%$ mortality on L. dispar larvae, respectively (Fig. 3).

Sezen et al. (2001) carried out a number of bioassays with S. marcescens, using larvae and/or adults of Agelastica alni, Balaninus nucum, Curculio elephas, Euproctis chrysorrhoea, Hyphantria cunea, Malocosoma neustria, Neodiprion sertifer, Pieris brassicae, and Y. malinellus. They determined 70 and $48 \%$ effect on the larvae and adults of $A$. alni, respectively; $78 \%$ on $B$. nucum adults, $55 \%$ on the larvae of C. elephas, $58 \%$ on E. chrysorrhoea, $10 \%$ on $H$. cunea, $78 \%$ on M. neustria, $88 \%$ on N. sertifer,
$100 \%$ on P. brassicae, and $92 \%$ on Y. malinellus larvae. On the other hand, Lipa and Wiland (1972) found 100\% mortality on Agrotis sp., Mathew and Mohamed-Ali (1987) recorded $83.3 \%$ on C. cadambae larvae, and Onoviran et al. (1985) recorded 65-90\% mortality with $S$. marcescens on Glossiana spp.

\section{Conclusion}

Entomopathogenic bacteria are generally known as lower risk pesticides than chemical pesticides. Five entomopathogenic bacteria were isolated from the forest common pests; $D$. micans, $T$. pityocampa, and $L$. dispar. The results confirmed that the five bacteria originated from $M$. melolontha larvae and infected the three tested pests. Therefore, the results of this study would be of great interest to propose some effective entomopathogenic bacteria against these important forest pests.

\section{Acknowledgements \\ Not applicable.}

\section{Authors' contributions}

ÖE collected insects and isolated and characterized bacteria and carried out biossay experiments. MY identified the bacteria, collected insects, and wrote the manuscript. Both authors read and approved the final manuscript.

\section{Funding}

Not applicable.

Availability of data and materials

All datasets are presented in the main manuscript.

Ethics approval and consent to participate

Not applicable.

Consent for publication

Not applicable.

Competing interests

The authors declare that they have no competing interests. 


\section{Author details}

'Department of Molecular Biology and Genetics, Faculty of Arts and Sciences, Ordu University, 52750 Ordu, Turkey. ${ }^{2}$ Department of Biology, Faculty of Arts and Science, Bolu Abant Izzet Baysal University, 14030 Bolu, Turkey.

Received: 9 May 2019 Accepted: 14 August 2019

Published online: 29 August 2019

\section{References}

Abbott WS (1925) A method of computing the effectiveness of an insecticide. J Econ Entomol 18:265-267

Ben-Dov E, Boussiba S, Zaritsky A (1995) Mosquito larvacidal activity of Escherichia coli with combinations of genes from Bacillus thuringiensis subsp. israelensis. J Bacteriol 177:2851-2857

Bucher GE, Stephens JM (1959) Bacteria of grasshoppers of Western Canada: II. The Pseudomonadaceae, Achromobacteriaceae, Micracaccaceae, Brevibaeteriaceae, Lactobacillaceae, and less important families. J Insect Pathol 1:374-390

Cockburn C, Amoroso M, Carpenter M, Johnson B, McNeive R, Miller A, Nichols AE, Riotto A, Rzepkowzski A, Croshaw CMS, Seifert K, Vaidyanathan R (2013) Gram-positive bacteria isolated from the common bed bug, Cimex lectularius L. Entomologica Americana 119:23-29

Egami I, liyama K, Zhang P, Chieda Y, Ino N, Hasegawa K, Shimizu S (2009) Insecticidal bacterium isolated from an ant lion larva from Munakata, Japan. J Appl Entomol 133(2):117-124. https://doi.org/10.1111/j.1439-0418.2008.01329.x

Hyliš M, Weiser J, Oborník M, Vávra J (2005) DNA isolation from museum and type collection slides of microsporidia. J Invertebr Pathol 88:257-260

Katı H, Katı A, Uğraş S, Yılmaz H (2017) Xyleborinus saxesenii (Coleoptera: Curculionidae)'den İole Edilen Bakterilerin Tanımlanması. Karadeniz Fen Bilimleri Dergisi 7(1):85-101

Kuzina LV, Peloquin JJ, Vacek DC, Miller TA (2001) Isolation and identification of bacteria associated with adult laboratory Mexican fruit flies, Anastrepha ludens (Diptera; Tephritidae). Curr Microbiol 42:290-294

Lauzon CR, Bussert TG, Sjogren RE, Prokopy RJ (2003) Serratia marcescens as a bacteria pathogen of Rhagoletis pomonella flies (Diptera: Tephritidae). Eur J Entomol 100:87-92

Lipa JJ (1975) An Outline of Insect Pathology. Published for the U.S. Department of Agriculture and the National Science Foundation, Washington D.C., by the Foreign Scientific, Technical and Economic Information Warsaw, Poland.

Lipa JJ, Wiland E (1972) Bacteria isolated from cutworms and their infectivity to Agrotis sp. Acta Microbiol Polonica 4:127-140

Lysenko O (1963) The mechanism of pathogenicity of Pseudomonas aeruginosa (Schroeter) Migula. 1. The pathogenity of strain N-06 for larvae of the Greater Wax Moth, Galleria mellonella (Linnaeus). J Insect Pathol 5:78-82

Mathew G, Mohamed-Ali M (1987) Microbial pathogens causing mortality in the carpenter worm, Cossus cadambae Moore (Lepidoptera, Cossidae), a pest of teak (Tectona gmndis Lin. f.) in kerala (India). J Trop For 3:349-35

Mezzatesta ML, Gona F, Stefani S (2012) Enterobacter cloacae complex: clinical impact and emerging antibiotic resistance. Future Microbiol. 7:887-902. https://doi.org/10.2217/fmb.12.61

Muratoğlu H, Sezen K, Demirbağ Z (2011) Determination and pathogenicity of the bacterial flora associated with the spruce bark beetle, Ips typographus (L.) (Coleoptera: Curculionidae: Scolytinae). Turk J Biol 35:9-20. https://doi.org/1 0.3906/biy-0902-12

O'Callaghan M, Garnham ML, Nelson TL, Baird D, Jackson TA (1996) The pathogenicity of Serratia Strains to Lucilia sericata (Diptera: Calliphoridae). J Invertebr Pathol 68:22-27

Onoviran O, Hamman HJ, Adeegboye DS, Ajufo JC, Makinde AA, Pam G, Garba A (1985) A bacterium pathogenic to tsetse fty (Glossina palpalis). Trop Veterin 3:22-24

Pineda-Castellanos M, Rodríguez-Segura Z, Villalobos FJ, Hernández L, Lina L, NuñezValdez ME (2015) Pathogenicity of isolates of Serratia marcescens towards larvae of the Scarab Phyllophaga blanchardi (Coleoptera). Pathogens 4:210-228

Ruiu L, Satta A, Floris I (2013) Emerging entomopathogenic bacteria for insect pest management. Bull Insectology 66:181-186

Sezen K, Demir I, Demirbağ Z (2007) Identification and pathogenicity of entomopathogenic bacteria from common cockchafer, Melolontha melolontha(Coleoptera: Scarabaeidae). N Z J Crop Hortic Sci 35:79-85

Sezen K, Yaman M, Demirbağ Z (2001) Insecticidal potential of Serratia marcescens Bn10. Biologia 56:333-336
Thiery I, Frachon E (1997) Identification, isolation, culture and preservation of enthomopathogenic bacteria. In: Lacey LA (ed) Manual of Techniques in Insect Pathology. Academic Press, London, pp 55-77

Yaman M, Algı G, Güner BG, Ertürk Ö, Ünal S, Radek R (2016) First record, occurrence and distribution of entomopathogens in populations of the European cockchafer, Melolontha melolontha (Coleoptera: Scarabaeidae) in Turkey. North-Western J Zool 12(1):192-195

Yaman M, Demirbağ Z (2000) Studies of the bacterial flora as a microbial control agent of the large white Pieris brassicae L. (Lepidoptera: Pieridae). Afr Entomol 8:144-148

Yaman M, Ertürk Ö (2016) Isolation, identification and insecticidal effects of entomopathogenic bacteria from the willow flea beetle, Crepidodera aurata (Coleoptera; Chrysomelidae). Prog Plant Prot 56(2):225-229. https://doi.org/1 0.14199/ppp-2016-037

Yaman M, Ertürk O, Aslan I (2010) Isolation of some pathogenic bacteria from the great spruce bark beetle, Dendroctonus micans and its specific predator, Rhizophagus grandis. Folia Microbiologica 55:35-38

Yaman M, Ertürk Ö, Ünal S, Selek F (2017) Isolation and identification of bacteria from four important poplar pests. Revista Colombiana de Entomología 43(1):34-37

Zimmermann G, Huger AM, Kleespies RG (2013) Occurrence and prevalence of insect pathogens in populations of the codling moth, Cydia pomonella L.: A long-term diagnostic survey. Insects 4:425-446. https:// doi.org/10.3390/insects4030425

\section{Publisher's Note}

Springer Nature remains neutral with regard to jurisdictional claims in published maps and institutional affiliations.

\section{Submit your manuscript to a SpringerOpen ${ }^{\circ}$ journal and benefit from:}

- Convenient online submission

- Rigorous peer review

- Open access: articles freely available online

High visibility within the field

- Retaining the copyright to your article

Submit your next manuscript at $\boldsymbol{\nabla}$ springeropen.com 